УДК 364.3 (477)

JEL classification: H55, 132,138, N30

DOI: https://doi.org/10.35774/visnyk2020.02.108

\title{
Радміла ПІдлипнА,
}

доктор економічних наук, професор кафедри обліку та оподаткування, Ужгородський торговельно-економічний інститут Київського національного торговельно-економічного університету.

Православна набережна, 21, м. Ужгород, 88000, Україна

E-mail: radmila2008@ukr.net

ORCIDID: 0000-0001-6886-5834

\section{МІСЦЕ СОЦІАЛЬНОГО СТРАХУВАННЯ У ФОРМУВАННІ РЕСУРСІВ СИСТЕМИ СОЦІАЛЬНОГО ЗАХИСТУ}

Підлипна Р. Місце соціального страхування у формуванні ресурсів системи соціального захисту. Вісник Тернопільського національного економічного університету. 2020. Вип. 2. С. 108-120. DOI: https://doi.org/10.35774/visnyk2020.02.108

Pidlypna, R. (2020). Mistse sotsialnoho strakhuvannia u formuvanni resursiv systemy sotsialnoho zakhystu. [The place of social insurance in the formation of resources of the social protection system]. The Herald of Ternopil National Economic University, Vol. 2. P. 108-120. DOI: https://doi.org/10.35774/visnyk2020.02.108

\section{Анотація}

Вступ. Сьогодні виникає потреба у застосуванні ефективних та дієвих методів і засобів державного регулювання соціальної сфрери, що підносить на новий рівень систему соціального захисту загалом та систему соціального страхування зокрема. Розвиток оптимальної системи соціального страхування є одним із пріоритетів соціальної стратегії держави та повинен розглядатися як підсистема соціального захисту населення, спрямованого на подолання бідності, забезпечення відповідного рівня і якості життя населення України.

Мета. Основним завданням статmі $є$ виявлення місия фрінансових ресурсів соціального страхування у системі соціального захисту населення в Україні шляхом аналізу поточної статистичної інфоомації.

Meтоди. В основу дослідження покладено оперативний та системноструктурний аналіз поточної статистичної інформації щодо накопичення $i$ розподілу бюджетних коштів у соціальній сфрері. Кількісне та якісне порівняння, графрічні і статистичні методи використано для аналізу і оцінювання ефективності розвитку системи соціального страхування.

(C) Радміла Підлипна, 2020. 
Результати. Значна частина видатків соціального захисту населення в Україні покривається за рахунок коштів фондів загальнообов'язкового державного соціального страхування, що свідчить про його ключову роль у забезпеченні соціального захисту населення України. Водночас, формування ресурсів соціальної інфраструктури здійснюється переважно за рахунок бюджетного фрінансування, тому постійне зростання видатків соціального спрямування у зведеному бюджеті України не дозволяє забезпечувати високий рівень життя населення. Соціальному страхуванню притаманне часткове самофінансування, адже воно передбачає формування фондів за рахунок соціальних внесків, які на третину фрінансують соціальні допомоги та інші соціальні трансферти. Отож, воно виступає дійовим інструментом забезпечення державного регулювання соціальної сфрери.

Перспективи. У подальшому дослідження доцільно зосередити на вивченні світової практики формування ефективних систем соціального страхування 3 метою пошуку альтернативних видів соціального страхування та запровадження їх в Україні.

Ключові слова: соціальні видатки;соціальні внески; соціальні гарантії; бюджет; джерела фрінансування.

Формул: 0, рис.: 5, табл.: 4, бібл.: 15.

\section{Abstract}

\section{Radmila PIDLYPNA}

\section{PLACE OF SOCIAL INSURANCE IN THE FORMATION OF RESOURCES OF THE SOCIAL PROTECTION SYSTEM}

Introduction. Today there is a need for the application of effective and efficient methods and means of state regulation of the social sphere, which raises to a new level the social protection system in general and the social insurance system in particular. The development of an optimal social insurance system is one of the priorities of the state's social strategy and should be considered as a subsystem of social protection aimed at overcoming poverty, ensuring the appropriate level and quality of life of the population of Ukraine.

Purpose. The main task of the article is to identify the place of financial resources of social insurance in the system of social protection in Ukraine by analyzing current statistical information.

Methods. The study is based on operational and system-structural analysis of current statistical information on the accumulation and distribution of budget funds in the social sphere. Quantitative and qualitative comparison, graphical and statistical methods are used to analyze and evaluate the effectiveness of the social insurance system.

Results. A significant part of the expenditures of social protection of the population in Ukraine is covered by the funds of the obligatory state social insurance, which testifies to its key role in ensuring the social protection of the population of Ukraine. At the same time, the formation of social infrastructure resources is carried out mainly through budget funding, so the constant growth of social expenditures in the consolidated budget of Ukraine does not allow to ensure a high standard of living. Social insurance is characterized by partial 
self-financing, as it provides for the formation of funds through social contributions, which finance a third of social benefits and other social transfers. Thus, it is an effective tool for ensuring state regulation of the social sphere.

Discussion. In the further research it is expedient to focus on studying world practice of formation of effective systems of social insurance for the purpose of search of alternative types of social insurance and their introduction in Ukraine.

Keywords: social expenditures; social contributions; social guarantees; budget; sources of funding.

Formulas: 0, fig.: 5, tabl.: 4, bibl.: 15.

Актуальність дослідження та постановка проблеми. В умовах нестійкості, нестабільності, постійних змін та реформ особливої ваги набувають питання адаптації соціальної складової державної політики України до потреб часу, адже її ефективність та дієвість безпосередньо впливає на добробут громадян та, безперечно, залежить від ефективного ресурсного забезпечення. Трансформації у економічній, політичній та соціальній сорерах на міжнародному рівні безпосередньо приводять до змін пріоритетів відповідних національних політик та актуалізують питання, пов'язані із забезпеченням вищого рівня та якості життя людей [1]. Однак у зв'язку із слабким та нестійким розвитком численні країни, в тому числі й Україна, не в змозі адекватно слідувати глобальним тенденціям, а їхня політика соціального захисту не відповідає рівню розвитку суспільних відносин в економіках добробуту. Тому сьогодні виникає потреба у застосуванні більш ефективних та дієвих методів та засобів державного регулювання соціальної сфери, що піднесло б на новий рівень систему соціального захисту загалом та систему соціального страхування зокрема. Розвиток оптимальної системи соціального страхування є одним із пріоритетів соціальної стратегії держави та повинен розглядатися як підсистема соціального захисту населення, спрямованого на подолання бідності, забезпечення відповідного рівня і якості життя та підвищення рівня державного регулювання соціального страхування.

Аналіз останніх наукових досліджень і публікацій. Питання фрінансового забезпечення соціальної політики досліджувалось багатьма вітчизняними дослідниками. Так, Грубляк, А. Мацкуляк вивчали роль бюджетування в реалізації соціальних програм [2], Л. Лисяк, В. Зюзін обґрунтовували засади цільового програмного бюджетування [3], Т. Биркович досліджувала принципи державного регулювання соціального розвитку [4], І. Прокопенко, Ю. Олійник вивчали особливості впливу соціальної політики на економічний розвиток держави [5].

Низка досліджень присвячена аспектам соціального страхування. Так, С. Качула розглядала зміни законодавчої бази фінансового забезпечення державних фондів соціального страхування в Україні [6]. С. Березіна здійснила порівняльний аналіз систем страхування у розвинутих країнах з практикою соціального страхування в Україні [7]. Питання координації систем соціального забезпечення в країнах ЄС були в центрі уваги дослідження S. Giubboni, F. ludicone, M. Mancini, M. Faioli [8]. C. Коваль запропонував авторські підходи до трактування соціального страхування і здійснив порівняльний аналіз джерел фрінансування виплат в Україні та Німеччині [9]. Т. Кривошлик зазначив, що українська модель соціального страхування передбачає 
активну участь держави в соціальному забезпеченні і порівняв тенденції розвитку соціального страхування за кордоном та в Україні [10]. Заслуговують на увагу запропоновані автором шляхи реформування соціального страхування шляхом сполучення можливостей соціального та комерційного страхування. Слід зазначити, що до подібних висновків приходять і E. Blanco, E. Dutcher G.Haller, які вивчали соціальні дилеми державного і приватного страхування [11]. Предметом досліджень О. Білозір були проблеми соціального страхування та системи соціальної захищеності країни в умовах європейської інтеграції [12].

Своєчасність та актуальність проведених авторами досліджень різних аспектів соціального страхування політикою не викликає жодного сумніву, однак подальший розвиток наукової думки в царині соціального управління потребує оперативного аналізу поточної інформації щодо накопичення і розподілу бюджетних коштів у соціальній сорері.

Формулювання цілей статті. Основним завданням статті є виявлення місця фінансових ресурсів соціального страхування у системі соціального захисту населення в Україні шляхом аналізу поточної статистичної інформації.

\section{Викладення основного матеріалу дослідження.}

Ефективна реалізація функцій соціальної держави потребує гармонізації цілей та завдань у всіх суміжних сферах суспільного життя, адже забезпечення високого рівня людського розвитку вимагає відповідних джерел фінансування, збалансування яких із потребами розвитку неможливе без існування зваженої економічної та фрінансової політики. Однією з базових умов успішного розвитку соціально орієнтованої ринкової економіки є розвинена система соціального страхування як фундаментальна основа та інструмент державного регулювання, з використанням якого мінімізується значна частина соціальних ризиків і загроз.

Попри наявність в Україні інституційно-організаційних засад функціонування, ефективність цієї системи залишається низькою, що підтверджується недостатнім пенсійним забезпеченням, нерозвиненістю системи медичного страхування, низьким рівнем соціальної безпеки та захищеності працюючих, що негативно позначається та перешкоджає, по-перше, формуванню інтелектуально-кадрового ресурсу розвитку національної економіки і, по-друге, перетворень соціального страхування на один із чинників, стимулів, а також фінансово-ресурсну передумову соціально-економічного розвитку держави. Водночас, світовий досвід накопичив різні моделі соціального страхування (табл. 1).

\section{Таблиця 1}

Моделі соціального страхування

\begin{tabular}{|c|l|l|}
\hline $\begin{array}{l}\text { № } \\
\text { з/п }\end{array}$ & Коротка характеристика & Переваги / недоліки \\
\hline & $\begin{array}{l}\text { Соціальні виплати узалежнено від зовнішніх } \\
\text { Іинникв - зайнятості застрахованої особи в } \\
\text { тій чи іншій галузі, займаної посади тощо }\end{array}$ & $\begin{array}{l}\text { соціального захисту; } \\
- \text { тісно пов'язаний із бюджетним } \\
\text { наповненням; } \\
\text { породжує психологію соціального } \\
\text { приманства }\end{array}$ \\
\hline
\end{tabular}


продовження таблиці 1

\begin{tabular}{|c|l|l|}
\hline \multirow{2}{*}{ II } & $\begin{array}{l}\text { Внески на соціальне страхування не } \\
\text { враховують соціальний ризик, адже } \\
\text { страхування здійснюється на користь третіх } \\
\text { осіб }\end{array}$ & $\begin{array}{l}\text { - відсутній взаємозв'язок між обсягом } \\
\text { накопичення коштів та розмірами } \\
\text { зобов'язань, що може призвести до } \\
\text { значного дедріциту }\end{array}$ \\
\hline \multirow{2}{*}{ III } & $\begin{array}{l}\text { Розмір накопичених коштів корелює із } \\
\text { зобов'язаннями, а виплати із розмірами } \\
\text { внесків. Здійснюється страхування окремих } \\
\text { видів ризиків }\end{array}$ & $\begin{array}{l}\text { дає змогу своєчасно й у достатньому } \\
\text { розмірі здійснювати соціальні виплати. }\end{array}$ \\
\hline
\end{tabular}

Джерело: складено на основі [8].

Реалізація першої моделі у Греції, як відомо, призвела свого часу до значних суспільних та економічних деформацій, що сприяло поширенню кризових явищ країною. Основний принцип другої моделі покладено у формування солідарної системи пенсійного забезпечення, яка має місце в Україні, i, як можна зауважити, основний недолік цієї моделі саме проявляється сьогодні у вигляді значного дефіциту, адже на виплати впливають такі фрактори, як депопуляція населення, зростання рівня безробіття в умовах економічної кризи тощо. Третя модель найбільш поширена в багатьох розвинутих країнах, адже дозволяє із достатнім ступенем точності визначати, які виплати можуть бути здійснені та $є$, по-суті, найоптимальнішою 3 позицій синхронізації видатків із реальними джерелами покриття як в обсязі, так і в часі.

За механізмами фрінансування соціальних видатків розрізняють північноєвропейський варіант (Ірландія, Великобританія та скандинавські країни) та континентальний (Франція, Німеччина, Бельгія, Нідерланди, США) (табл. 2).

Таблиця 2

Порівняльна характеристика північноєвропейської та континентальної моделей соціального страхування

\begin{tabular}{|l|c|c|}
\hline \multicolumn{1}{|c|}{ Показник } & $\begin{array}{c}\text { Північноєвропейська } \\
\text { модель }\end{array}$ & $\begin{array}{c}\text { Континентальна } \\
\text { модель }\end{array}$ \\
\hline Частка соціальних видатків у ВВП & $\approx 40 \%$ & $\approx 30 \%$ \\
\hline Частка соціальної сфрери у видатках бюджету & $\approx 15 \%$ та вище (значна) & незначна \\
\hline $\begin{array}{l}\text { Частка фрінансування соціальних видатків за } \\
\text { рахунок системи соціального страхування }\end{array}$ & максимально до 50\% & $\approx 65 \%$ і вище \\
\hline $\begin{array}{l}\text { Частка фрінансування соціальних видатків за } \\
\text { рахунок бюджету }\end{array}$ & більше $50 \%$ & менше $50 \%$ \\
\hline
\end{tabular}

Джерело: розроблено за даними [13].

Проаналізуємо значення перелічених вище показників в Україні у 2014-2019 рр. (табл. 3). 


\section{Динаміка окремих показників фінансування соціальних видатків} в Україні у 2014-2019 рр.

\begin{tabular}{|l|c|c|c|c|c|c|c|}
\hline \multicolumn{1}{|c|}{ Показники } & 2014 & 2015 & 2016 & 2017 & 2018 & 2019 & $\begin{array}{c}2019 / \\
2014, \%\end{array}$ \\
\hline ВВП, млрд. грн. & 1586,9 & 1988,5 & 2383,2 & 2982,9 & 3558,7 & 4080,2 & 257,1 \\
\hline Частка соціальної сфери у ВВП, \% & 20,8 & 20,1 & 21,1 & 20,9 & 19,7 & 18,7 & 89,9 \\
\hline $\begin{array}{l}\text { Частка соціальної сфери у видатках } \\
\text { бюджету, \% }\end{array}$ & 63,2 & 58,7 & 60,3 & 59,1 & 56,2 & 55,8 & 88,4 \\
\hline $\begin{array}{l}\text { Частка фрінансування соціальних } \\
\text { видатків за рахунок системи } \\
\text { соціального страхування, \% }\end{array}$ & 67,5 & 63,9 & 55,3 & 55,2 & 58,7 & 58,0 & 86,0 \\
\hline $\begin{array}{l}\text { Частка фрінансування соціальних } \\
\text { видатків за рахунок бюджету, \% }\end{array}$ & 20,1 & 19,0 & 19,4 & 20,1 & 22,0 & 21,3 & 106,2 \\
\hline
\end{tabular}

Джерело: розраховано за даними [14, 15].

Як бачимо, за критерієм механізму фінансування соціальних видатків вітчизняна модель соціального страхування наближається до континентальної, однак протягом досліджуваного періоду частка фрінансування соціальних видатків за рахунок системи соціального страхування скоротилася, що свідчить про зниження ефективності системи соціального страхування загалом. Порівняння соціальних виплат із мінімальними соціальними гарантіями дозволяє стверджувати, що за соціальним спрямуванням країна скоріше належить до системи соціального страхування американського типу, адже прожиткові мінімуми розраховуються, виходячи із споживчого кошика, також варто зауважити, що виплати по безробіттю все ще не досягають рівня мінімальної заробітної плати. Отже, сьогодні, виходячи із ресурсних можливостей, наша держава може гарантувати лише забезпечення мінімальних потреб громадян.

Саме тому досить важливою є проблема розподілу фрінансової відповідальності між суб'єктами соціального захисту. Страхові платежі розподіляються між роботодавцями та застрахованими особами, а також між державними та місцевими органами влади (державним та місцевими бюджетами) (рис. 1). Загалом надходження фінансових ресурсів до системи соціального захисту зросли за досліджуваний період у 2,13 рази.

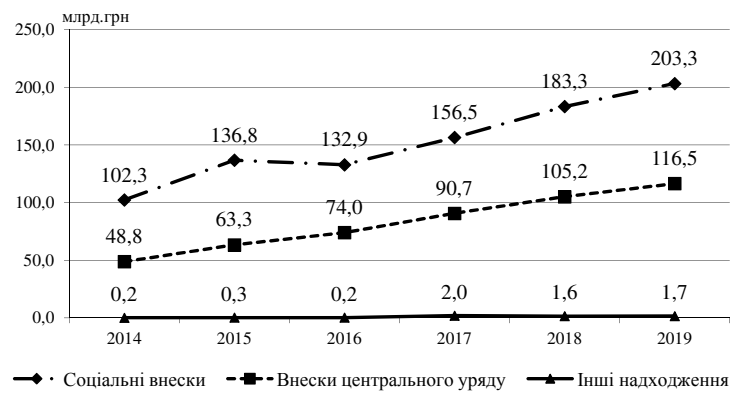

Рис. 1. Динаміка джерел фрінансування соціального захисту в Україні у 2014-2019 рр.

Джерело: побудовано за даними [14]. 
Серед основних джерел фрінансування системи соціального захисту в Україні найбільші суми надходжень припадають на соціальні внески роботодавців та застрахованих осіб, які за досліджуваний період зросли майже в два рази. Наступним за обсягом джерелом фрінансування системи соціального захисту виступають внески центрального уряду, а їх обсяги зросли за шість років у 2,4 рази, що є цілком закономірним, адже в умовах прагнення до соціальної держави роль держави у забезпеченні добробуту громадян зростає.

Співвідношення між джерелами фрінансування системи соціального страхування безпосередньо залежить від ролі та значення такої компоненти системи соціального захисту, як соціальне страхування. Таким чином, пропорції розподілу відповідальності між суб'єктами системи соціального захисту першочергово визначаються тим, що соціальному страхуванню притаманні ключові ознаки страхування, а тому основним джерелом все ж виступають страхові внески, тобто соціальні внески. Загалом частка соціальних внесків у формуванні ресурсів соціального захисту за період з 2014 р. до 2019 р. дещо скоротилася, поступившись внескам центрального уряду та іншим надходженням на кілька відсоткових пунктів. Однак соціальні внески роботодавців та застрахованих осіб все ж залишаються ключовим джерелом фінансування видатків соціального захисту.

У різних країнах Європи, згідно з принципом паритетності, соціальні внески в тій чи іншій пропорції поділяються між роботодавцями та застрахованими (табл. 4).

Таблиця 4

Пропорції розподілу соціального внеску між роботодавцями та застрахованими особами в окремих країнах Європи

\begin{tabular}{|c|c|c|}
\hline Країна & $\begin{array}{c}\text { Частка роботодавців відносно } \\
\text { загального внеску, \% }\end{array}$ & $\begin{array}{c}\text { Частка застрахованих } \\
\text { осіб, \% }\end{array}$ \\
\hline Австрія & 82,8 & 17,2 \\
\hline Іспанія & $\approx 80,0$ & $\approx 20,0$ \\
\hline Італія & $\approx 80,0$ & $\approx 20,0$ \\
\hline Люксембург & 85,0 & 15,0 \\
\hline Нідерланди & $\approx 33,0$ & $\approx 67,0$ \\
\hline Німеччина & 59,8 & 20,2 \\
\hline Угорщина & 88,5 & 11,5 \\
\hline Чехія & 87,5 & 12,5 \\
\hline
\end{tabular}

Джерело: розроблено за даними [13].

Щодо окремих видів соціального страхування, то зазвичай зберігається участь підприємств, самихпрацівників та держави. ВУкраїні основне навантаження соціальної відповідальності припадає на роботодавців, адже за рахунок їхніх внесків, а саме нарахувань на фронд оплати праці єдиного внеску на загальнообов'язкове державне соціальне страхування, у 2014-2019 рр. фрормувалось 90,5 \% усіх соціальних внесків (рис. 2). Тільки 9,5 \% соціальних внесків формувалось за рахунок надходжень від соціально захищених громадян, зокрема 2,3 \% внеску формували працюючі не по 
найму (приватні підприємці, самозайняті особи), пенсіонери та інші, а лише7,2 \% внеску фрормувалось за рахунок утримань із заробітної плати працівників.

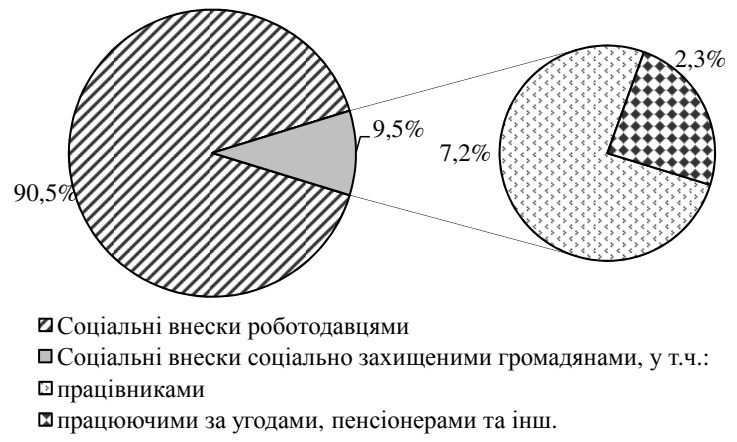

Рис. 2. Структура соціальних внесків за платниками в Україні у 2014-2019 рр. (усереднене значення)

Джерело: побудовано за даними [14].

Оскільки основним джерелом надходжень виступає єдиний внесок на загальнообов'язкове державне соціальне страхування, то актуалізуються питання його раціонального розподілу між фондами соціального страхування. Зокрема, за напрямами соціального захисту безробітних його частка у фрормуванні ресурсів складала у 2014-2019 р. в середньому 98,8\%, у сукупних надходженнях соціального захисту в разі професійної хвороби або нещасного випадку на виробництві - 99,5\%, у формуванні ресурсів соціального захисту в разі тимчасової втрати працездатності 99\%, а у надходженнях соціального захисту пенсіонерів - 99,4\% (рис. 3).

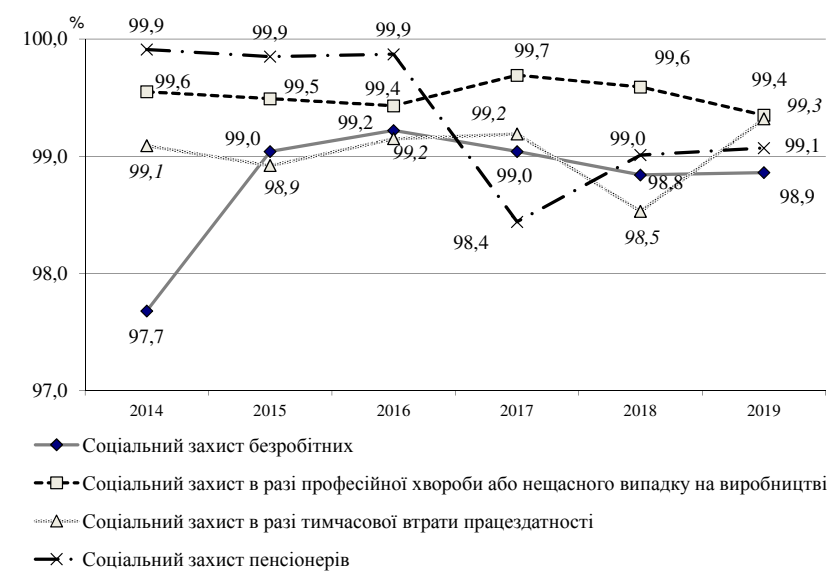

Рис. 3. Динаміка частки соціальних внесків у джерелах фрінансування соціального захисту за видами соціального страхування в Україні у 2014-2019 рр.

Джерело: побудовано за даними [14].

Хоча основна частка фрінансування соціального захисту загалом та соціального страхування зокрема припадає на роботодавців, варто зазначити, що останніми роками виявляється тенденція до збільшення ролі внесків соціально захищених 
громадян у формуванні ресурсів соціального захисту, адже частка соціальних внесків соціально захищеними громадянами за проаналізований період зросла у структурі сукупних джерел фрінансування соціального захисту у 1,8 рази, що свідчить про часткове перенесення навантаження 3 роботодавців на найманих працівників та державу (рис. 4).Тобто, сьогодні трохи більше половини видатків соціального захисту фрінансується саме завдяки внескам роботодавців, більше третини - за рахунок внесків центрального уряду та 8,7\% за рахунок внесків соціально захищених громадян.

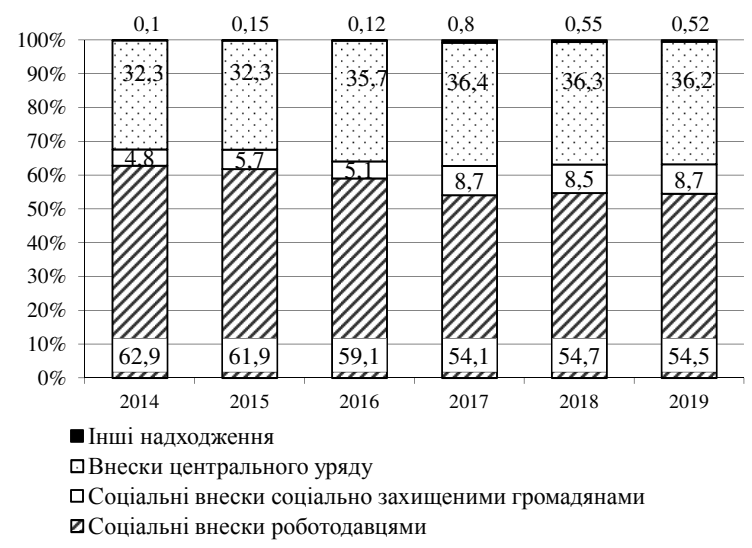

Рис. 4. Структура джерел фінансування соціального захисту в Україні за розподілом відповідальності у 2014-2019 рр.

Джерело: побудовано за даними [14].

Формування ресурсів соціального захисту відбувається за різними напрямками, а саме: кошти соціального захисту пенсіонерів зросли у 2,06 рази, ресурси соціального захисту в разі тимчасової втрати працездатності у 1,83 рази, кошти соціального захисту в разі професійної хвороби або нещасного випадку на виробництві у 2,09 рази, кошти соціального захисту безробітних у 2,18 рази, кошти інших напрямів соціального захисту населення практично у 2,5 рази. Інші напрямки соціального захисту передбачають формування коштів за рахунок таких джерел, як: охорона здоров'я, соціальний захист сімей, соціальний захист військовослужбовців, компенсації житлових витрат, соціальний захист осіб, які постраждали внаслідок аварії на Чорнобильській АЕС та ін. (рис. 5).

Отож, близько 60 \% усіх джерел фінансування соціального захисту складають кошти фондів соціального страхування, що фрормуються згідно із законодавством для виконання їх закріплених функцій і завдань і включають єдиний внесок на загальнообов'язкове державне соціальне страхування, інвестиційний дохід, асигнування із Державного бюджету України, суми від фінансових санкцій, а також благодійні і добровільні внески та часткову оплату санаторно-курортного лікування. 


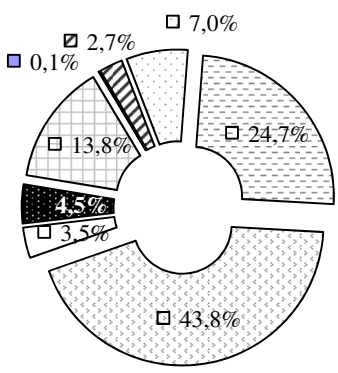

口Лікарняні каси

चСоціальні виплати роботодавців

口Компенсація житлових витрат

口Соціальний захист сімей

๑Охорона здоров'я

口Соціальний захист працівників державного управління

- Соціальний захист осіб, які постраждали внаслідок аварії

на Чорнобильській АЕС

口Соціальний захист військовослужбовців

Рис. 5. Структура джерел формування коштів соціального захисту за іншими напрямками в Україні у 2014-2019 рр. (усереднене значення)

Джерело: побудовано за даними [14].

Таким чином, більше половини видатків соціального захисту населення в Україні покривається за рахунок коштів фондів загальнообов'язкового державного соціального страхування, що свідчить про його ключову роль у забезпеченні соціального захисту населення України. Водночас, формування ресурсів соціальної інфраструктури здійснюється переважно за рахунок бюджетного фрінансування, тому видатки соціального спрямування у зведеному бюджеті України зростають не лише номінально, а й реально, однак це не дозволяє забезпечувати високий рівень життя населення. Для України показник задоволення життям становить 5,0, що є нижчим як від середнього показника у світі, так і від середнього значення у країнах $€ C$ [8]. Населення суттєво узалежнено від соціальних допомог, адже, по-перше, їхнє значення у формуванні доходів населення $€$ надзвичайно відчутним та становить більше третини сукупних доходів, а, по-друге, роль населення у фінансуванні цих допомог є дуже незначною - в середньому близько трьох відсотків, решта за рахунок коштів роботодавців та найманих працівників. Соціальному страхуванню притаманне часткове самофрінансування, адже воно передбачає формування фондів за рахунок соціальних внесків, які на третину фінансують соціальні допомоги та інші соціальні трансферти. За таких умов соціальне страхування стає дійовим інструментом забезпечення державного регулювання соціальної сфери.

Висновки. Система соціального страхування в Україні $€$ окремим сегментом відносин у системі соціальної сфери держави та провідним інструментом державної соціальної політики, що являє собою сукупність елементів і взаємозв'язків між ними, які визначають систему прав, обов'язків і гарантій з надання соціального захисту працездатної частини суспільства, що створює матеріальні і нематеріальні блага. Формування ресурсів системи соціального захисту населення в Україні в основному покладено на систему фондів соціального страхування, що поряд із бюджетним фінансуванням соціального забезпечення та соціальних допомог у межах провадження соціальної політики повинно забезпечити соціальні гарантії, подолання бідності, а також достойний рівень і якість життя громадян.

Перспективи подальших досліджень. Оскільки оцінка розподілу та використання сформованих ресурсів засвідчила їхню недостатню ефективність, подальше дослідження доцільно зосередити на вивченні світової практики формування 
ефективних систем соціального страхування з метою пошуку альтернативних видів соціального страхування та запровадження їх в Україні.

\section{תimepamypa}

1. European Union. Social security. URL: https://europa.eu/youreurope/business/ human-resources/social-security-health/social-security/index_en.htm (дата звернення08.05.2020).

2. Грубляк О. М., Мацкуляк А. А. Роль бюджету в реалізації соціальної політики держави. Молодий вчений. 2018. № 10 (2). С. 761-764.

3. Лисяк Л. В., Зюзін В. О. Механізм фрінансового забезпечення соціальних програм в Україні. Економічний вісник університету: збірник наукових праць Переяслав-Хмельницького державного педагогічного університету ім. Г. Сковороди. 2018. № 37 (1). С. 236-245.

4. Биркович Т. І. Вплив трансформаційних процесів у державі на формування принципів державного регулювання соціально-культурного розвитку. Інвестиції: практика та досвід. 2018. № 3. С. 86-89.

5. Прокопенко І. Ф., Олійник Ю. О. Державна соціальна політика як чинник економічного розвитку України. Збірник наукових праць ХНПУ. 2018. № 18. C. 4-13.

6. Качула С. Фінансове забезпечення діяльності державних фондів соціального страхування в Україні. Наукові записки Національного університету «Острозька академія». Серія: Економіка. 2018. Вип. 10. С. 68-72.

7. Березіна С. Б. Порівняльна оцінка національної і закордонних систем страхування. Економіка та держава. 2018. № 6. С. 37-43.

8. Giubboni S., ludicone F., Mancini M., Faioli M. Coordination of Social Security Systems in Europe. Brussels: European Parliament, 2017. 116 p.

9. Коваль С. Л. Система державного соціального страхування: досвід України та Німеччини. Світ фрінансів. 2018. № 2 (55). С. 67-77.

10. Кривошлик Т. Д. Вплив тенденцій соціального страхування на розвиток системи страхового захисту в Україні. Бізнес Інфоорм. 2018. № 12 (491). С. 239-245.

11. Blanco E., Dutcher E. Haller G., Social dilemmas with public and private insurance against losses. Journal of Economic Behavior \& OrganizationIn press. 2019. https:// doi.org/10.1016/j.jebo.2019.02.008

12. Білозір О. В. Проблеми соціального страхування та системи соціальної захищеності країни в умовах європейської інтеграції. Інвестиції: практика та досвї. 2019. № 23. С. 140-143.

13. OECD. StatExtracts: Complete database. Organisation for economic co-operation and development. URL: http://stats.oecd.org/\# (дата звернення 08.05.2020).

14. Державна служба статистики України. Офіційний web-pecypc. URL: http://www. ukrstat.gov.ua/ (дата звернення 27.04.2020).

15. Міністерство фрінансів України. Видатки зведеного бюджету за роками. 20142019. URL: https://index.minfin.com.ua/ua/finance/budget/cons/expense/2019/. 


\section{References}

1. European Union (2017). Social security. Retrieved fromhttps://europa.eu/ youreurope/business/human-resources/social-security-health/social-security/ index_en.htm [in English].

2. Hrubliak, O. M., \& Matskuliak, A. A. (2018). Rol biudzhetu v realizatsii sotsialnoi polityky derzhavy [The role of the budget in the implementation of the social policy of the state]. Molodyi vchenyi - Young Scientist, 10 (2), 761-764 [in Ukrainian].

3. Lysiak, L. V., \& Ziuzin, V. O. (2018). Mekhanizm finansovoho zabezpechennia sotsialnykh prohram $v$ Ukraini [The mechanism of financial support of social programs in Ukraine]. Ekonomichnyi visnyk universytetu: zbirnyk naukovykh prats Pereiaslav-Khmelnytskoho derzhavnoho pedahohichnoho universytetu im. $H$. Skovorody -Economic Bulletin of the University: Collection of Scientific Papers of Pereyaslav-Khmelnitsky G. Skovorody State Pedagogical University, 37 (1), 236245 [in Ukrainian].

4. Byrkovych, T. I. (2018). Vplyv transformatsiinykh protsesiv u derzhavi na formuvannia pryntsypiv derzhavnoho rehuliuvannia sotsialno-kulturnoho rozvytku [Influence of transformation processes in the state on the formation of principles of state regulation of socio-cultural development]. Investytsii: praktyka ta dosvid Investments: Practice and Experience, 3, 86-89 [in Ukrainian].

5. Prokopenko, I. F., \& Oliinyk, Yu. O. (2018). Derzhavna sotsialna polityka yak chynnyk ekonomichnoho rozvytku Ukrainy [State social policy as a factor of economic development of Ukraine]. Zbirnyk naukovykh prats KhNPU imeni H.S. Skovorody "Ekonomika» - Collection of scientific works of KhNPU named after G.S. Skovoroda "Economy", 18, 4-13 [in Ukrainian].

6. Kachula, S. (2018). Finansove zabezpechennia diialnosti derzhavnykh fondiv sotsialnoho strakhuvannia $v$ Ukraini [Financial support for the activities of state social insurance funds in Ukraine]. Naukovi zapysky Natsionalnoho universytetu "Ostrozka akademiia» - Scientific Notes of Ostroh Academy National University, 10, 68-72 [in Ukrainian].

7. Berezina, S. B. (2018). Porivnialna otsinka natsionalnoi i zakordonnykh system strakhuvannia [Comparative assessment of national and foreign insurance systems]. Ekonomika ta derzhava - Economy and State, (6), 37-43 [in Ukrainian].

8. Giubboni S., ludicone F., Mancini M., \& Faioli M. (2017). Coordination of Social Security Systems in Europe. Brussels: European Parliament. 116 p. [in English].

9. Koval, S. L. (2018). Systema derzhavnoho sotsialnoho strakhuvannia: dosvid Ukrainy ta Nimechchyny [State social insurance system: the experience of Ukraine and Germany]. Svit finansiv - World of Finance, 2 (55), 67-77 [in Ukrainian].

10. Kryvoshlyk, T. D. (2018). Vplyv tendentsii sotsialnoho strakhuvannia na rozvytok systemy strakhovoho zakhystu v Ukraini [The impact of social insurance trends on the development of the insurance protection system in Ukraine]. Byznes Inform Business Inform, 12 (491), 239-245 [in Ukrainian].

11. Blanco E., Dutcher E., \& Haller G. (2019). Social dilemmas with public and private insurance against losses. Journal of Economic Behavior \& OrganizationIn press. Retrieved from https://doi.org/10.1016/j.jebo.2019.02.008. [in English]. 
12. Bilozir, O. V. (2019). Problemy sotsialnoho strakhuvannia ta systemy sotsialnoi zakhyshchenosti krainy $v$ umovakh yevropeiskoi intehratsii [Problems of social insurance and social security system of the country in the context of European integration]. Investytsii: praktyka ta dosvid - Investments: Practice and Experience, (23), 140-143 [in Ukrainian].

13. OECD. (2020). StatExtracts: Complete database. Organisation for economic cooperation and development. Retrieved from http://stats.oecd.org/\# [in English].

14. Derzhavna sluzhba statystyky Ukrainy. (2020). Ofitsiinyi web-resurs [Official web resource]. Retrieved from http://www.ukrstat.gov.ua/ [in Ukrainian].

15. Ministerstvo finansiv Ukrainy. (2020). Vydatky zvedenoho biudzhetu za rokamy. 2014-2019 [Consolidated budget expenditures by years. 2014-2019]. Retrieved from https://index.minfin.com.ua/ua/finance/budget/cons/expense/2019/ [in Ukrainian].

Статтю отримано 10 квітня 2020 р.

Article received April 10, 2020 